\title{
User embracement and risk classification at obstetric emergency: evaluating operationalization in a maternity hospital school
}

\author{
Acolhimento do usuário e classificação de risco em emergência obstétrica: avaliação da \\ operacionalização em maternidade-escola
}

\section{Acogimiento del usuario y clasificación de riesgo en emergencia obstétrica: evaluación de la operacionalización en una maternidad escuela}

\begin{abstract}
Maria das Neves Figueiroa ${ }^{1}$
Maria Lucia Neto de Menezes ${ }^{1}$

Estela Maria Leite Meirelles Monteiro²

Jael Maria de Aquino ${ }^{1}$

Nathalia de Oliveira Gonzaga Mendes ${ }^{1}$

Priscila Vanessa Tavares da Silva ${ }^{1}$
\end{abstract}

1. Universidade de Pernambuco.

Recife, PE, Brazil.

2. Universidade Federal de Pernambuco.

Recife, PE, Brazil.
Corresponding author:

Maria das Neves Figueiroa.

E-mail: nevesfigueiroa@hotmail.com

Submitted on 05/23/2017.

Accepted on 09/09/2017.

DOI: 10.1590/2177-9465-EAN-2017-0087

\begin{abstract}
Objective: To evaluate the functioning of a user embracement and risk classification service in a maternity hospital school in Recife, Pernambuco, Brazil. Method:Observational, cross-sectional, and analytical study with a quantitative approach, conducted at the "Amaury de Medeiros" Integrated Health Center of the University of Pernambuco (CISAM/UPE), in April and May 2015. The sample consisted of 377 female users and 6 nurses, with the application of Stork Network's user embracement and risk classification protocol. Results: The waiting time according to risk classification was $21.2 \mathrm{~min}$; the duration time was 5 min; the waiting time according to the red priority was $3.5 \mathrm{~min}$. The spontaneous demand showed that $56 \%$ of the users were classified as green priority, $60 \%$ of the users reported dissatisfaction, and $33 \%$ of the nurses received training. Conclusions: The service under analysis needs agreements and assessments to promote coping strategies.
\end{abstract}

Keywords: User Embracement; Monitoring; Evaluation; Women's Health

\section{Resumo}

Objetivo: Avaliar o funcionamento de um serviço de acolhimento e classificação de risco em uma maternidade-escola, em Recife-PE. Método: Estudo observacional, transversal e analítico com abordagem quantitativa, realizado no Centro Integrado de Saúde Amaury de Medeiros da Universidade de Pernambuco(Cisam/UPE), em abril e maio de 2015. A amostra fo composta por 377 usuárias e seis enfermeiros, com utilização do instrumento de indicadores do protocolo de acolhimento $e$ classificação de risco da Rede Cegonha. Resultados: O tempo de espera pela classificação de risco foi 21,2 min.; o tempo de duração foi 5 min.; o tempo de espera segundo prioridade vermelha foi 3,5 min. A demanda espontânea demonstrou que $56 \%$ das usuárias foram classificadas como prioridade verde, $60 \%$ das usuárias relataram insatisfação e $33 \%$ dos enfermeiros receberam treinamento. Conclusões: $\mathrm{O}$ serviço em análise necessita de pactuações e avaliações para promover estratégias de enfrentamento de dificuldades.

Palavras-chave: Acolhimento; Monitoramento; Avaliação; Saúde da Mulher.

\section{Resumen}

Objetivo: Evaluar el funcionamiento de un servicio de acogimiento y clasificación de riesgo en una maternidad escuela en Recife, Pernambuco, Brasil. Método: Estudio observacional, transversal y analítico con abordaje cuantitativo, realizado en el Centro Integrado de Salud "Amaury de Medeiros" de la Universidad de Pernambuco (CISAM/UPE), en abril y mayo de 2015. La muestra estuvo compuesta por 377 usuarias y 6 enfermeros, utilizando el instrumento de indicadores del protocolo de acogida y clasificación de riesgo de la Red Cigüeña. Resultados: El tiempo de espera según la clasificación de riesgo fue de 21,2 min el tiempo de duración fue de $5 \mathrm{~min}$; el tiempo de espera según la prioridad roja fue de 3,5 min. La demanda espontánea mostró que el $56 \%$ de las usuarias fueron clasificadas como prioridad verde, el $60 \%$ de las usuarias reportaron insatisfacción y el $33 \%$ de los enfermeros recibieron capacitación. Conclusiones: El servicio bajo análisis necesita acuerdos y evaluaciones para promover estrategias de afrontamiento.

Palabras clave: Acogimiento; Monitoreo; Evaluación; Salud de la Mujer. 


\section{INTRODUCTION}

The concept of humanization can be understood as the valorization and inclusion of the different subjects involved in the hospital care process: users, employees, service providers, cooperatives and managers. ${ }^{1}$

In Brazil, since 1988, with the creation of the Unified Health System (UHS), the debates/discussions on humanization are aimed at consolidating the principles of universality, integrality and equality of care to the user. ${ }^{2}$

From the debates and discussions, the Ministry of Health $(\mathrm{MH})$ started from the premise that it is a right of every citizen to receive quality public health care. With a view to improving care in the UHS, in 2003, the MH created the National Humanization Policy (NHP) to welcome users and prioritize the most serious cases, and "HumanizaSUS" established the guideline called "reception with risk classification". ${ }^{3}$

In 2011, by initiative of the $\mathrm{MH}$, the Federal Government launched the Stork Network (SN), with the objective of providing a better quality of attention to women's health and to the health of the child. SN encourages the innovation and qualification of prenatal care, childbirth care and the postpartum period, as well as actions related to the child's development during the first two years of life. ${ }^{4}$ Thus, reception and classification are guarantees provided by the SN. ${ }^{4}$

Reception and risk classification lead to decision-making by the health professional based on active listening of patient complaints, associated with evidence-based clinical evaluation based on protocols. ${ }^{4}$

In obstetrics, the host presents peculiarities inherent to the needs and demands related to the pregnancy process, such as the investigation of common complaints during the gestational period, for example, headache, nausea, vomiting and blurred vision, which can mask clinical situations demanding rapid action; this requires preparation of health teams for qualified listening and accurate clinical judgment. ${ }^{4,5}$

In the specialty in focus, the classification of risk involves categories of severity, differentiated by colors:

- $\quad$ Red (emergent) - patients at risk of death;

- $\quad$ Orange (very urgent) - non-stabilized or semi-critical patients;

- Yellow (urgent) - critical or semi-critical patients already stabilized;

- $\quad$ Green (less urgent) - less critical patients, without risk of injury;

- $\quad$ Blue (non-urgent) - non-severe patients. ${ }^{3,4}$

The protocol of acceptance and classification of risk constitutes a tool to support clinical decision and universal language for obstetric emergencies. Its purpose is the prompt identification of critical or serious cases, enabling rapid and safe service based on evidences potential, and also basing and guiding a succinct and systematic analysis to identify life-threatening situations. ${ }^{4}$
The implementation of the reception protocol and risk classification requires follow-up evaluation processes to adjust and correct its effective operation. However, the review of the literature on obstetrics revealed a shortage of studies on the subject and deficiencies in the monitoring and evaluation of care flows.

Considering the indicators for monitoring and evaluation of $\mathrm{MH}$, the objective of this study was to evaluate the functioning of a shelter and risk classification service in a maternity reference for high-risk pregnancy in Recife, Pernambuco.

\section{METHOD}

This is an observational, cross-sectional and analytical study with a quantitative approach, ${ }^{6}$ conducted in April and May 2015 at the Amaury de Medeiros Integrated Health Center (CISAM), a unit of the hospital complex of the Universidade de Pernambuco (UPE), located in the Sanitary District II of Recife, which constitutes a maternity-school of reference in the state of Pernambuco for offering healthcare of medium and high complexity.

The study was based on observation and indicators of monitoring and evaluation of the host protocol and risk classification, implemented in CISAM in November 2013, after the reopening of the service in question.

The study population consisted of the users who were in the CISAM screening and the nurses who work in this hospital sector. The non-probabilistic sample was defined by means of a sample calculation of users by means of the Sample Size Calculator Raosoft, ${ }^{7}$ adopting a 50\% prevalence estimate, a $95 \%$ confidence interval and a $5 \%$ margin of error. ${ }^{8}$ We consider the number of patients treated in 2014 (377 subjects). Regarding the nurses, the sample consisted of the professionals present in the data collection period (6 subjects).

The inclusion criteria of the patients in the sample were: a) patients who sought or were referred for obstetric screening of CISAM. Exclusion criteria were: a) patients whose clinical conditions required emergency care that was beyond the routine of the reception protocol and risk classification; b) patients who were unable to answer questions;

Regarding the nurses in the sample, all day and night shift workers (who were present during the data collection period) were included, and the workers who were not part of the effective service function were excluded: as was the case with the residents.

The conceptual construct that supported the selection of analysis variables was the reception protocol and risk classification of $\mathrm{SN}$ of the $\mathrm{MH} .{ }^{4}$ The indicators analyzed were: 1) average time of waiting for the registry until the beginning of the risk classification;2) average time of risk classification; 3) the average waiting time from the end of the risk classification to the attendance by the physician or obstetrician by clinical priority; and 4) percentage of classifications according to clinical priority. Other parameters: 1) satisfaction of the user of the service; and 2) training of nurses in service. 
Data collection was performed in three moments, using an instrument prepared by the authors of this study: 1) application of a form to record the observations regarding waiting time from arrival to medical care; 2 ) interview of women attended to evaluate their satisfaction; and 3) survey of the in-service training situation of the professionals involved in the application of the host protocol and risk classification.

The data were organized in Microsoft Excel spreadsheets, Windows 7 version, and processed in the program GraphPad Prism. ${ }^{4}$ The results are presented in the form of graphs and tables and analyzed in light of the literature.

The research was developed in accordance with the precepts of Resolution n. 466/2012, of the National Health Council, which deals with the ethical aspects of research involving human beings. The study was approved by the Research Ethics Committee of UPE, under the Certificate of Presentation for Ethical Assessment (CAAE) n. 42106615.2.0000.5207 and Opinion no. 1,020,408, of April $13^{\text {th }}, 2015$.

\section{RESULTS}

Among the 377 patients included in the sample, $84 \%$ sought obstetric care and $16 \%$ sought gynecological care. Among the obstetric users, $64.4 \%$ were in the third trimester of gestation, $17 \%$ in the second trimester, $13.2 \%$ in the first trimester, $3.2 \%$ in the puerperium and $2.2 \%$ had a clinical condition of abortion or dead fetus. Among gynecological users, 38.3\% reported bleeding, $10 \%$ had amenorrhea to clarify and $51.7 \%$ reported other health problems.

The results showed that, when searching for the service, among the 377 patients in the sample, $74.5 \%$ were admitted to the service by spontaneous demand, $13.5 \%$ arrived at the service by referral, with a password from the central regulation of beds, coming from different services, $4.5 \%$ were referred by a specialized outpatient clinic and $7.4 \%$ came from primary health care (PHC).

Analyzing the quality indicators of the reception service and classification of risk, it was verified that the waiting time for the user to be classified corresponded, in average, to $21.2 \mathrm{~min}$. The average rating time was 5 minutes. In the evaluation of the time elapsed between classification and medical care, according to clinical priorities, it was identified that the red clinical priority had a mean wait time of $3.5 \mathrm{~min}$; the clinical priorities of orange, yellow, green and blue presented, respectively, $12.5 \mathrm{~min}$., $17.5 \mathrm{~min}$., 45.3 min. and 50.8 min (Table 1).

The fourth indicator, which corresponds to the evaluation of the prevalence of type of classification by clinical priority, indicated that $1 \%$ of cases involved the red category, $4 \%$ involved orange, $26 \%$ involved yellow, $56 \%$ involved green, and $13 \%$ involved the blue one.

Regarding the level of user satisfaction, $77 \%$ reported being satisfied or very satisfied, as shown in the Figure 1 below.

Table 1. Evaluation of the indicators proposed by the Ministry of Health at the Amaury de Medeiros Integrated Health Center. Recife, 2015

\begin{tabular}{|c|c|c|c|c|c|}
\hline Indicators & $\mathbf{N}$ & RV & AT & ASD & CV \\
\hline \multicolumn{6}{|l|}{ Indicator 1} \\
\hline Registration wait time until the beginning of the classification & 377 & $<10$ & 21.2 & 9.1 & $42 \%$ \\
\hline \multicolumn{6}{|l|}{ Indicator 2} \\
\hline Duration of risk classification & 377 & $<5$ & 5 & 2.3 & $48 \%$ \\
\hline \multicolumn{6}{|l|}{ Indicator 3} \\
\hline Medical attention wait according to red priority & 4 & 0 & 3.5 & 2.4 & $106 \%$ \\
\hline Medical attention wait according to orange priority & 11 & $\leq 15$ & 12.5 & 7.9 & $63 \%$ \\
\hline Medical attention wait according to yellow priority & 93 & $\leq 30$ & 17.5 & 11.5 & $71 \%$ \\
\hline Medical attention wait according to green priority & 218 & $\leq 120$ & 45.3 & 38.9 & $89 \%$ \\
\hline Medical attention wait according to blue priority & 51 & $\leq 240$ & 50.8 & 42.5 & $93 \%$ \\
\hline \multicolumn{6}{|l|}{ Indicator 4} \\
\hline Spontaneous demand: red priority & $4(1 \%)$ & & & & \\
\hline Spontaneous demand: orange priority & $11(4 \%)$ & & & & \\
\hline Spontaneous demand: yellow priority & $93(26 \%)$ & & & & \\
\hline Spontaneous demand: green priority & $218(56 \%)$ & & & & \\
\hline Spontaneous demand: blue priority & $51(13 \%)$ & & & & \\
\hline
\end{tabular}

RV: Reference Value of the Ministry of Health; AT: Average Time; ASD: Average Standard Deviation; CV: Coefficient of Variance. 
Figure 1. Level of user satisfaction of the Amaury de Medeiros Integrated Health Center. Recife, 2015. S: Satisfied; VS: Very Satisfied; LS: Little Satisfied; U: Unsatisfied.

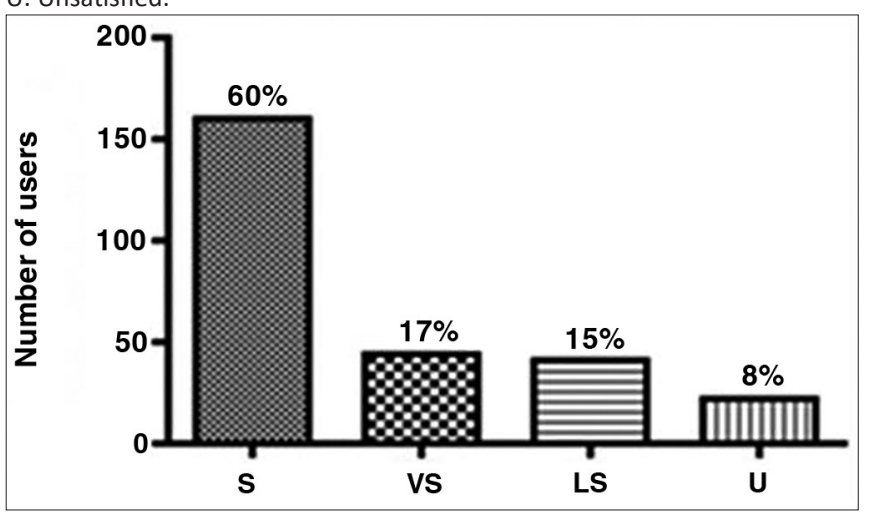

The analysis of the in-service capacitating and training related to the implementation and functioning of the reception protocol and risk classification indicated that only $33 \%$ of the nurses were previously trained to perform the reception with risk classification. The trainings were carried out by the permanent education team of the service (CISAM). However, part of the nurses were trained in other services where they also integrate the reception team and obstetric risk classification.

When questioned about the difficulties in implanting the reception protocol and classification of risk in the institution, nurses reported that during the first two years of execution, the service faced difficulties such as: lack of information material, banners and bracelets for signs of severity of patients (Figure 2).

Figure 2. Investigation of training service for nurses of the urgency of the Amaury de Medeiros Integrated Health Center. Recife, 2015. Source: Prepared by the authors.

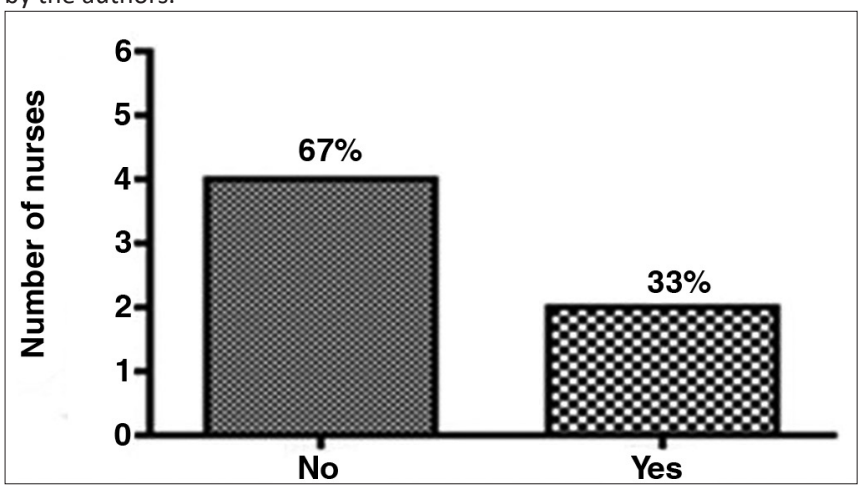

\section{DISCUSSION}

Data released by the Instituto Brasileiro de Geografia e Estatística (IBGE) in 2016 indicate that Brazil has a population of 206 million inhabitants. The Northeast region holds $28 \%$ of this population, and Pernambuco is one of the most populous states, with about 9.5 million residents - its capital, Recife, has a population estimated at 1.6 million inhabitants. ${ }^{9}$ In this city, there are $32 \%$ of women between 10 and 49 years of age (fertile age) and $13 \%$ of women over 50 years old and $6 \%$ of women (non-fertile age). ${ }^{10,11}$ Thus, there is a high prevalence of women of fertile age in the state, which justifies the profile of users who sought care in the service under analysis, which presents a high demand for obstetric care; although gynecological patients are also of fertile age in terms of women's health, the need for urgent care is related more frequently to obstetrics than to gynecology. Studies involving the Mobile Emergency Care Service ("SAMU"), regarding the total number of occurrences attended, identified that $10.66 \%$ of the occurrences were related to pregnancy, delivery and puerperium, confirming that, during the fertile age, pregnancy and its associated factors motivate a greater search for emergency services. ${ }^{12}$

The spontaneous demand stood out; this can be understood as the unexpected arrival of the user to the service, either by acute problems or for reasons that the patient itself considers health needs. ${ }^{13}$

The prevalence of spontaneous demand is due to the lack of adequate health policies and the low resolution of services, combined with the difficulty of changing cultural habits and beliefs of the population; thus, the user seeks medical care where there is an open door, that is, in the emergency services, which represent a possibility of more agile service, with availability of consultations, medication, nursing care, laboratory tests and hospitalizations, however, most of these patients should see their demands solved by the PHC services available in a basic health unit (BHU). ${ }^{14}$

Among the patients admitted to the service only $4 \%$ had an official referral, nonetheless, many of the women who entered spontaneously reported having been referred at the $\mathrm{BHU}$ to seek emergency care; adding this result to the percentage of spontaneous demand, we have $82 \%$ of the total emergency service entrances, causing them to be overcrowded. A study carried out in the Santa Catarina emergency service identified that the large flow of users seeking care is common, which is due to the lack of reference and counter-reference and impairs the quality of care. In addition, the establishment of reception and risk classification services should provide the right destination for this clientele, however, the growing population with insufficient resources in $\mathrm{PHC}$ ends up finding in the emergency service its only possibility of meeting needs of health. ${ }^{15}$

The reduction in the number of beds, a national measure implemented since 2010, has been aggravated, leading to a decrease of almost 42 thousand beds in the UHS throughout the country in recent years. In Pernambuco, this drop corresponded to $5.5 \%$, highlighting also that, among the specialties most affected by the cut, obstetrics occupies the third position. ${ }^{16}$ The reduction of bed supply and the lack of professionals and materials, associated with greater demand, intensify situations such as: 1) pilgrimage of parturient through maternity hospitals; 2) admissions of high-risk pregnant women on stretcher, chair or 
floor; and 3) high-risk pregnancy transfers due to lack of material resources or human resources (competent professional) to attend birth/delivery. ${ }^{17}$

In the health service, there are also the transfers of patients with passwords from the central regulation of beds of the state, passwords that provide access of UHS users to a referral service. Depending on the pathology defined by the attending physician, it will be up to the regulatory physician to formulate objective questions so that errors can be avoided, with consequent unnecessary referrals. ${ }^{18}$ Password demand, coupled with pacts between PHC services or specialized outpatient clinics, configures possibilities of organization of demand, avoiding pilgrimage, overcrowding and patient queues.

It should also be noted that, even in the face of the possibility of excessive demand, many women persist in opting for CISAM because they feel more welcomed and believe that they will find competent professionals in view of previous successful experiences - with themselves or with family members.

It is important to highlight that the system of classification and regulation of users by means of passwords can favor the ordering of queues and establish priorities, but the access logic, based on the classification of risk, can refer to the lack of reception and indifference of the professionals to the suffering of users by subjectively treating subjective aspects. ${ }^{19}$

The four indicators proposed by the $\mathrm{MH}^{3}$ Protocol evaluate and monitor the reception and risk classification service. The purpose is to: a) provide support to the process of assessing women's access to the emergency sector; b) guarantee, agree and monitor the directing flows; $\mathrm{c}$ ) monitor the resolution of the service in the hospital; and d) to organize the sector to provide a safe and humane assistance. ${ }^{4}$ The first indicator analyzed was the waiting period of the registry until the beginning of the classification, well above 10 minutes, exceeding the period recommended by the protocol. Excessive time spent in the waiting line increases the possibility of changing the usual risk scenario or aggravating high risk..$^{20} \mathrm{It}$ is believed that waiting is due to the high demand in the service, a problem that may also be related to the fact that there is a small number of hospitals in Pernambuco that offer referral services for high-risk cases, categorizing the obstetric bed crisis in the state.

The second indicator analyzed was the duration of the risk classification, a time that was discreetly out of target; this indicator should be less than 5 minutes, suggesting the need for greater agility for the professional who qualifies. The protocol ${ }^{3}$ is a tool to guide the evaluation of the severity and the risk of aggravation, the classification should be fast and dynamic to enable skilled attendance in more severe cases, being necessary the reassessment of the risk of the patients not yet served or that the waiting time exceeds the time predicted by the protocol. ${ }^{3}$ The analysis of the third indicator, time of medical care according to clinical priority, showed that it is in accordance with the goal of $\mathrm{MH}^{3}{ }^{3}$
Regarding the fourth indicator, the classification of the red, orange and yellow clinical priorities, respectively, "emergent", "very urgent" and "urgent", summed only $31 \%$ and the green and blue classifications, respectively, "little urgent" and "nonurgent", totaled $69 \%$, that is, many referrals did not fit the profile of the service, considering that it is a reference service for high risk pregnancy. These results are compatible with findings from a study conducted in Ribeirão Preto, SP ${ }^{21}$ in 2011, which indicates the use of services with a higher technological density by patients with $\mathrm{PHC}$ compatible complaints. It is believed that the overvaluation of the hospital-centered model is a contributing factor for: a) overcrowding of urgency/emergency services; b) restriction of operating hours of the $\mathrm{BHU}$; c) difficulty finding schedules available at the UBS; d) greater availability of resources in the early care than in the $\mathrm{BHU}$; e) complaints regarding the service offered at $\mathrm{BHU}$; and $\mathrm{f}$ ) considering themselves a user with urgent care demand. These are some of the reasons that justify the patients' choices in UHS presented in the study carried out in Ribeirão Preto. ${ }^{21}$

A survey on the evaluation of user satisfaction showed that $65.7 \%$ of the patients said they were satisfied about the waiting time between the arrival and the end of the service, corroborating the reality observed in the maternity in analysis, revealing a positive evaluation by the majority of users $(77 \%){ }^{22}$

However, it is important to explore and understand the reasons that leave the users unsatisfied because some dissatisfaction may occur due to the disagreement between the risk established by the classification professional and the risk that the own user or their relatives believe that they should be given. ${ }^{23}$

The record of patient satisfaction seeking CISAM's urgency/ emergency service reveals the readability of these users of the service. Studies that address user satisfaction are important, since they reveal the users' view on the resolvability of care and seem to contribute to the organization and improvement of health services..$^{24}$ Apparently, this finding is positive, however, it must be considered that women may not be an excellent standard for the assessment of care. It is important that women are satisfied with the available service and this cannot be disregarded; however, their parameters of satisfaction analysis may be submerged in life experiences with little knowledge about social control, participation in USH, and citizenship rights.

The nurse is the professional indicated by the $\mathrm{MH}^{3}$ to provide the risk classification, a reality observed in the health service under analysis; among the professionals that are dedicated to the classification, $33 \%$ received in-service training, a value considered unsatisfactory, since the nursing process and permanent education are paramount to guarantee the quality of patient and family care and the safety of the staff of health. ${ }^{25}$

In the maternity hospital, the implantation of the protocol of reception and classification of risk is considered recent, which demands training due to the change in the operation of the 
service. In this sense, the technical training is fundamental to adjust the risk classification, making the nurse follow the $\mathrm{MH}^{3}$ flow chart and capable of assessing the patients' clinical conditions, their level of consciousness, ventilation and circulation, their pain, their vital signs and their symptoms, considering the risk factors and making possible the attendance by clinical priority. ${ }^{4}$

The study presents limitations because it deals with a specific reality, which makes it impossible to generalize its results. However, its contribution lies in the possibility of boosting the monitoring of care flows in services with reception and risk classification that can evidence valid methodological strategies to be applied in other health units and the results may serve as subsidies for the improvement of classification services risks offered to the population.

\section{FINAL CONSIDERATIONS}

The implantation of the reception protocol and classification of risk in the institution took place effectively, though, during its first two years, the execution faced difficulties reported by the nurses, such as lack of information material, banners and wristbands for signaling patients' severity and devices able to promote guidance and prevent questions and conflicts between patients.

The great challenge lies in the reduction of spontaneous demand, only possible when there are agreements with the PHC services or the specialized services, something that would help in the organization of the work process and the improvement of the service.

Regarding their satisfaction, the majority of the users declared themselves satisfied with the waiting time from the arrival at the reception until the medical attention. Reception and risk classification are organized by the $\mathrm{MH}$ flowchart; the importance of training of nursing professionals is fundamental for a standardized classification that obeys the flowchart of the protocol, due to the peculiarities of pregnancy care that demand rapid action, requiring the professional preparation for qualified listening and the capacity for accurate clinical judgment. Which the user or his or her family members believe is framed.

This study found that the operation of the CISAM obstetric and gynecological urgency/emergency service requires constant reassessments, with monthly monitoring, in which results should be discussed with management and workers to share difficulties and create coping strategies; the reports of the evaluations may subsidize changes in the $\mathrm{MH}$ risk classification form.

\section{REFERENCES}

1. Ministério da Saúde (BR). Cadernos HumanizaSUS: Humanização do parto e do nascimento. Brasília (DF): Ministério da Saúde; 2014.
2. Cavalcante RB, Rates HF, Silva LTC, Mello RA, Dayrrel KMB. Greeting to risk rating: proposal humanization in emergency services. Rev Enferm Cent Oeste Min [Internet]. 2012 Sep/Dec; [cited 2015 May 20] 2(3):428-37. Available from: http://seer.ufsj.edu.br/index.php/recom/ article/view/288/356

3. Ministério da Saúde (BR). Acolhimento e classificação de risco nos serviços de urgência. Brasília (DF): Ministério da Saúde; 2009.

4. Ministério da Saúde (BR). Manual de acolhimento e classificação de risco em obstetrícia. Brasília (DF): Ministério da Saúde; 2014.

5. Lacerda IC, Moreira TMM. Características obstétricas de mulheres atendidas por pré-eclâmpsia e eclampsia. Acta Sci Health Sci [Internet]. 2011; [cited 2017 Oct 25]; 33(1):71-6. Available from: http://www. periodicos.uem.br/ojs/index.php/ActaSciHealthSci/article/view/7711. DOI: 10.4025/actascihealthsci.v33i1.7711

6. Rouquayrol MZ, Almeida Filho N. Introdução à Epidemiologia. $7^{\underline{a}}$ ed. Rio de Janeiro: Guanabara Koogan; 2013. 296 p.

7. Raosoft. Sample Size Calculator. Seattle (WA): Raosoft; 2004. [Internet]. [cited 2014 Nov 27]. Available from: http://www.raosoft.com/samplesize. html

8. Pereira MG. Epidemiologia:Teoria e Prática. Rio de Janeiro: Guanabara Koogan; 2008.

9. Ministério do Planejamento (BR). Cidades [Internet]. Rio de Janeiro: IBGE; 2016. [cited 2017 Mar 15]. Available from: http://www.cidades. ibge.gov.br/xtras/uf.php?coduf=33

10. Ministério do Planejamento (BR). IBGE. Estimativas da população residente no Brasil e unidades da Federação com data de referência em $1^{\circ}$ de julho de 2016. [Internet]. Rio de Janeiro: IBGE; 2016. [cited 2017 Mar 15]. Available from: http://ftp.ibge.gov.br/Estimativas_de_ Populacao/Estimativas_2016/estimativa_2016_TCU.pdf

11. Ministério do Planejamento (BR). IBGE. Indicadores sociais municipais Uma análise dos resultados do universo do Censo Demográfico 2010. [Internet]. Rio de Janeiro: IBGE; 2011. [cited 2015 May 20]. Available from: http://biblioteca.ibge.gov.br/visualizacao/livros/liv54598.pdf

12. Silva NC, Nogueira LT. Avaliação de indicadores operacionais de um serviço de atendimento móvel de urgência. Cogitare Enferm [Internet]. 2012 Jul/Sep; [cited 2017 Mar 15]; 17(3):471-7. Available from: http:// revistas.ufpr.br/cogitare/article/viewFile/29287/19037

13. Ministério da Saúde (BR). Acolhimento à demanda espontânea. Brasília (DF): Ministério da Saúde; 2011

14. Brilhante AF, Vasconcelos CTM, Bezerra RA, Lima SKM, Castro RCMB, Fernandes AFC. Implementação do protocolo de acolhimento com classificação de risco em uma emergência obstétrica. Rev RENE [Internet]. 2016 Jul/Aug; [cited 2017 Mar 15];17(4):569-75. Available from: http://periodicos.ufc.br/rene/article/view/4966/0. DOI: 10.15253/2175-6783.2016000400018

15. Nascimento ERP, Hilsendeger BR, Neth C, Belaver GM, Bertoncello KCG. Classificação de risco na emergência: avaliação da equipe de enfermagem. Rev Enferm UERJ [Internet]. 2011 Jan/Mar; [cited 2017 Mar 15]; 19(1):84-8. Available from: http://www.facenf.uerj.br/v19n1/ v19n1a14.pdf

16. Conselho Federal de Medicina (BR). Crise na assistência: falta de financiamento impacta no número de leitos e prejudica trabalho médico [Internet]. 2012. [cited 2017 Mar 15]. Available from: http://portal.cfm. org. br/index.php?option=com_content\&view=article\&id=23234: $\mathrm{cr}$ se-na-assistencia-falta-de-financiamento-impacta-no-numero-deleitos-e-prejudica-trabalho-medico\&catid $=3$

17. Assunção MF, Soares RC, Serrano I. A superlotação das maternidades em Pernambuco no contexto atual da política de saúde. Serv Soc Rev [Internet]. 2014 Jan/Jun; [cited 2017 Mar 15]; 16(2):5-35. Available from: http://www.uel.br/revistas/uel/index.php/ssrevista/article/ viewFile/14401/15183 DOI: 10.5433/1679-4842.2014v16n2p5

18. Pernambuco (Estado). Central de regulação de leitos: manual operacional. Recife: Secretaria Estadual de Saúde; 2014. [s.p]. 
19. Moreira DA, Tibães HBB, Batista RCR, Cardoso CML, Brito MJM. Manchester triage system in primary health care: ambiguities and challenges related to access. Texto Contexto Enferm [Internet]. 2017 Jun; [cited 2017 Jul 11]; 26(2):e5970015. Available from: http://www.scielo.br/scielo.php?script=sci_arttext\&pid=S010407072017000200302\&lng=en. http://dx.doi.org/10.1590/010407072017005970015

20. Matos DPM, Queiroz APO, Lima FET. Dificuldades e benefícios do acolhimento com classificação de risco nos hospitais municipais de Fortaleza. In: XXVIII Encontro de Iniciação Científica da Universidade Federal do Ceará. Fortaleza: Anais do XXVIII Encontro de Iniciação Científica da Universidade Federal do Ceará; 2009.

21. Caccia-Bava MCG, Pereira MJB, Rocha JSY, Martinez EZ. Prontoatendimento ou atenção básica: escolhas dos pacientes no SUS. Medicina (Ribeirão Preto) [Internet]. 2011; [cited 2017 Mar 15] 44(4):347-54. Available from: http://www.revistas.usp.br/rmrp/ article/view/47446. DOI: http://dx.doi.org/10.11606/issn.2176-7262. v44i4p347-354
22. Pereira AVL. Avaliação da satisfação dos usuários do setor de internamento de um hospital público em Campina Grande-PB [dissertação]. Recife: Fundação Oswaldo Cruz; 2013. 79 p.

23. Oliveira JLC, Gatti AP, Barreto MS, Bellucci Junior JA, Góes HLF, Matsuda LM. Acolhimento com classificação de risco: percepções de usuários de uma unidade de pronto atendimento. Texto Contexto Enferm [Internet]. 2017 Feb; [cited $2017 \mathrm{Jul}$; 26(1):e0960014. Available from: http://dx.doi.org/10.1590/0104-07072017000960014. http://dx.doi. org/10.1590/0104-07072017000960014

24. Rosa RB, Pelegrini AHW, Lima MADS. Resolutividade da assistência e satisfação de usuários da Estratégia Saúde da Família. Rev Gaúch Enferm [Internet]. 2011 Jun; [cited 2017 Mar 15]; 32(2):345-51. Available from: http://seer.ufrgs.br/index.php/RevistaGauchadeEnfermagem/ article/view/18574/12782

25. Santana JCB, Fortes NM, Monteiro CLA, Carvalho IM, Leonardo LMU, Albuquerque PG. Assistência de enfermagem em um serviço de terapia renal substitutiva: implicações no processo do cuidar. Enferm Rev [Internet]. 2012; [cited 2017 Oct 25]; 15(2):168-78. Available from: http:// periodicos.pucminas.br/index.php/enfermagemrevista/article/view/4082 